\title{
Anthropogenic Impacts on American Eel Demographics in Hudson River Tributaries, New York
}

\author{
LEONARD S. MACHUT* \\ College of Environmental Science and Forestry, State University of New York, 1 Forestry Drive, Syracuse, \\ New York 13210, USA; and U.S. Geological Survey, Tunison Laboratory of Aquatic Science, \\ 3075 Gracie Road, Cortland, New York 13045, USA \\ KARIN E. LIMBURG \\ College of Environmental Science and Forestry, State University of New York, \\ 1 Forestry Drive, Syracuse, New York 13210, USA \\ ROBERT E. SCHMIDT \\ Bard College at Simon's Rock, 84 Alford Road, Great Barrington, Massachusetts 01230, USA \\ Dawn DitTMan \\ U.S. Geological Survey, Tunison Laboratory of Aquatic Science, \\ 3075 Gracie Road, Cortland, New York 13045, USA
}

\begin{abstract}
Populations of American eel Anguilla rostrata along the eastern coast of North America have declined drastically for largely unknown reasons. We examined the population dynamics of American eels in six tributaries of the Hudson River, New York, to quantify their distribution and the impacts of anthropogenic stressors. With up to 155 American eels per $100 \mathrm{~m}^{2}$, tributary densities are greater than those within the main stem of the Hudson River and are among the highest reported anywhere. The predominance of small American eels $(<200 \mathrm{~mm})$ and wide range of ages (from young-of-year glass eels to 24-year-old yellow eels) suggest that tributaries are an important nursery area for immature American eels. However, upstream of natural and artificial barriers, American eel densities were reduced by at least a factor of 10 and condition, as measured by mass, was significantly lower. Significantly lower American eel condition was also found with increasing riparian urbanization. Density-dependent growth limitations below barriers are suggested by increased growth rates above the first tributary barrier. We suggest that (1) tributaries are important habitat for the conservation of American eels and (2) mitigation of anthropogenic stressors is vital for complete utilization of available habitat and conservation of the species.
\end{abstract}

Complexities in the management of anadromous and catadromous fisheries over marine fisheries involve the use of multiple ecosystems-freshwater streams and lakes, estuaries, coastal marine waters, and the open ocean-to complete species' life cycles. Noted declines in many anadromous species found on the Atlantic Coast include river herrings Alosa spp., striped bass Morone saxatilis (but now recovered), and sturgeons Acipenser spp. (Kahn and Buerger 1994; Smith and Clugston 1997; Limburg et al. 2003; Schmidt et al. 2003). These declines have been linked to overfishing, the fragmentation or limitation of habitat caused by dams, and pollution as a result of urbanization. Recent concerns regarding the health of anguillid fishes in general, and the American eel Anguilla rostrata in particular, have been raised as well (e.g., ASMFC

\footnotetext{
* Corresponding author: 1machut@usgs.gov
}

Received June 16, 2006; accepted June 25, 2007

Published online December 10, 2007
2000, 2006; ICES 2004); specific concerns center on a lack of understanding of the basic biology of American eels and reliable estimates of stock abundance and distribution (ASMFC 2006). In watersheds of Europe, where habitat for the European eel Anguilla anguilla has been reduced by at least 33\% (Feunteun 2002), combinations of reduced recruitment, nonsustainable commercial catch of immigrating glass eels and emigrating silvering eels, pollution, and climate change have led to a precipitous decline in European eel stocks, perhaps beyond safe biological limits (ICES 2004). The American eel, the subject of our study, is in general decline along the eastern coast of North America (Castonguay et al. 1994; Richkus and Whalen 1999; Haro et al. 2000). Commercial landings of American eels in New York State, averaging 61.2 metric tons from 1950 to 2003, have fallen to less than 0.2 metric tons/year from a high of 209 metric tons in 1980 (NMFS 2005), and recent glass eel recruitment to Hudson River tributaries showed declines from 10.6 to 


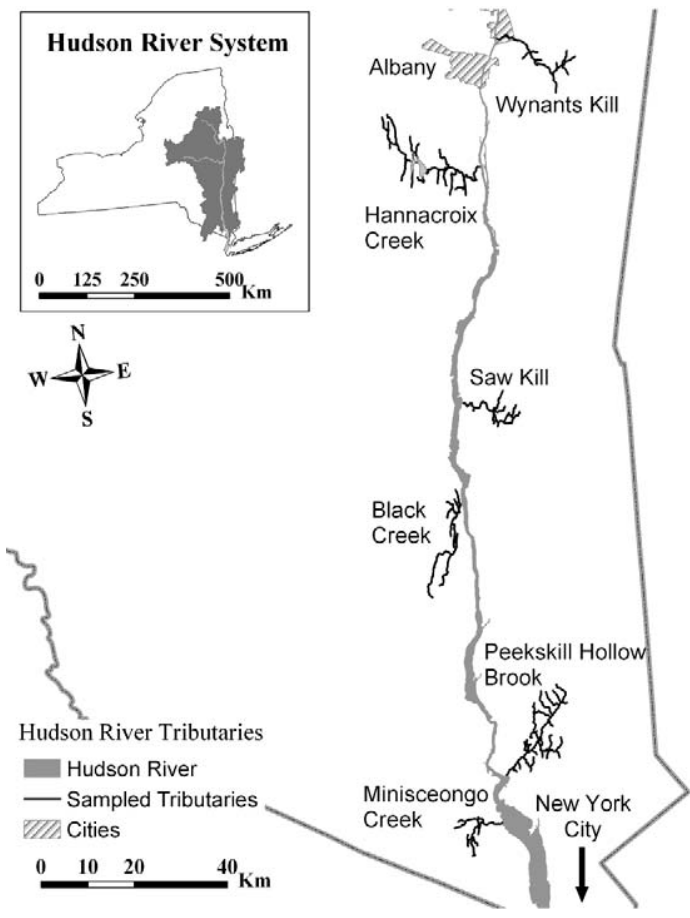

Figure 1.-Map of the Hudson River estuary showing the six tributaries in which American eels were studied.

3.3 eels/d from 2003 to 2005 before increasing in 2006 (R. E. Schmidt, Bard College at Simon's Rock, unpublished data).

Barriers may impede the progress of American eels into upstream habitats. Up to $84 \%$ of riverine habitat in the U.S. eastern seaboard and Lake Ontario drainages are upstream of dams (Busch et al. 1998). Eels are thought to be able to migrate past barriers only when they are smaller than $250 \mathrm{~mm}$ (Jellyman 1977; Legault 1988; Haro and Krueger 1991) by creeping up vertical walls or using areas of low flow. Barriers may also restrict movement between habitats (Cairns et al. 2004). However, most studies of barrier impacts to upstream migration have been conducted on large river systems (McGrath et al. 2003; Verdon and Desrochers 2003); little work has been performed within smaller tributaries.

Additional anthropogenic effects from urbanization may also impact American eels. In general, urbanization and introduced pollutants may affect fish condition and distribution in a watershed (Limburg and Schmidt 1990; Wang et al. 1997; Wolter et al. 2000; Coghlan and Ringler 2005). Urbanization may also alter aquatic invertebrate communities (Lenat and Crawford 1994; Moore and Palmer 2005), which American eels depend on as macroinvertebrate predators. Given the mounting evidence of the effects of land use change, tributary urbanization may be a second contributing factor in American eel decline in continental watersheds.

While broad geographic studies have shown latitudinal gradients in American eel growth and age at maturity (Helfman et al. 1987; Jessop 1987; Morrison and Secor 2003), questions remain about differences among stock densities, age, length, and growth within the longitudinal gradients of smaller streams. Conditions within small streams may exert controls on the growth of the American eel (Oliveira and McCleave 2000). However, there is little documentation of American eels in small tributaries connected to larger freshwater systems. While studies of American eel stocks and production within the Hudson River estuary main stem have estimated American eel densities $\left(0.03-0.24\right.$ eels $\left./ 100 \mathrm{~m}^{2}\right)$ and freshwater growth (34 mm/year; Morrison and Secor 2003, 2004), no estimates have been produced in tributaries draining into the Hudson River estuary. We argue that these areas are important habitat for yellow-phase American eels, and may contribute a portion of the estuary stock disproportionately important in relation to their area.

Non-fisheries-related anthropogenic impacts on American eels in Hudson River tributaries can be examined within the watershed because of polychlorinated biphenyl contamination of the main stem and the resultant closure of commercial fisheries since 1976. This reduced fishing mortality to negligible levels and allowed us to examine population demographics in the absence of this often dominant factor. Small tributaries of the Hudson River estuary provide opportunities to examine the impact of anthropogenic stressors, to gauge the relative importance of this habitat in relation to the main stem, and to assess their importance in conservation strategies. Specifically, we address the following questions: (1) Does American eel relative abundance vary longitudinally in tributaries, particularly with respect to barriers? (2) How does condition vary along an urbanization gradient or with increasing barrier intensity? (3) Are age and growth rates affected by barriers? (4) Are stock attributes (density, age, growth, and condition) different in tributaries than within the main stem of the Hudson River?

\section{Study Site}

The Hudson River estuary is located in eastern New York State (Figure 1). Over 100 tributaries empty into the Hudson River below the first barrier on the main stem, the federal dam at Troy, New York (river kilometer [rkm] 252; rkm $0=$ The Battery, Manhattan Island, New York.). Thus, immigrating American eels have unimpeded access to the estuary and into the mouths of sample tributaries. Six tributaries of the 
TABLE 1.-Watershed characteristics for censused Hudson River tributaries at which yellow-phase American eels were collected, 2003-2004.

\begin{tabular}{|c|c|c|c|c|c|c|c|c|c|}
\hline Tributary & $\begin{array}{l}\text { Watershed } \\
\text { area }\left(\mathrm{km}^{2}\right)\end{array}$ & $\begin{array}{c}\text { Distance from } \\
\text { Hudson River } \\
\text { mouth }(\mathrm{km})\end{array}$ & $\begin{array}{c}\text { Stream } \\
\text { length } \\
(\mathrm{km})\end{array}$ & $\begin{array}{c}\text { Eel } \\
\text { penetration } \\
(\mathrm{km})^{\mathrm{a}}\end{array}$ & $\begin{array}{c}\text { Number of } \\
\text { barriers }\end{array}$ & $\begin{array}{l}\text { Distance to } \\
\text { first barrier } \\
\text { (m) }\end{array}$ & $\begin{array}{l}\text { First barrier } \\
\text { height }(\mathrm{m})\end{array}$ & $\begin{array}{l}\% \text { Artificial } \\
\text { barrier }^{b}\end{array}$ & $\begin{array}{c}\text { Average } \\
\text { barrier } \\
\text { height }(\mathrm{m})\end{array}$ \\
\hline Wynants Kill & 85.47 & 232.5 & 25.95 & 5.0 & 7 & 20 & 1.70 & 43 & 3.51 \\
\hline Hannacroix Creek & 166.24 & 204.4 & 37.81 & 31.0 & 4 & 1,985 & 3.50 & 40 & 4.39 \\
\hline Saw Kill & 66.29 & 153.8 & 22.62 & 11.0 & 7 & 255 & 1.34 & 43 & 3.27 \\
\hline Black Creek & 87.77 & 132.4 & 29.55 & 27.5 & 9 & 2,620 & 4.40 & 22 & 2.47 \\
\hline Peekskill Hollow Brook & 135.51 & 69.2 & 28.11 & 23.5 & 4 & 3,825 & 3.74 & 100 & 1.81 \\
\hline Minisceongo Creek & 47.90 & 58.0 & 18.86 & 9.0 & 6 & 1,900 & 0.75 & 100 & 2.51 \\
\hline
\end{tabular}

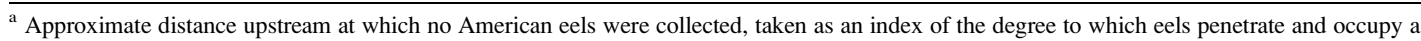
particular tributary.

b Barriers were separated into two classes: (1) natural waterfalls and (2) artificial (man-made) barriers, such as mill pond dams.

Hudson River estuary were selected for sampling (Table 1): Wynants Kill, Hannacroix Creek, Saw Kill, Black Creek, Peekskill Hollow Brook, and Minisceongo Creek. Streams predominantly were wadable from source to sink, and sampling was carried out in water less than $1 \mathrm{~m}$ in depth. Streams with large numbers of barriers were paired with streams having relatively few barriers along a north-south gradient from Troy to West Haverstraw, New York (rkm 58). Within each tributary, six to seven stream segments averaging $45 \mathrm{~m}$ in length (range, $21.0 \mathrm{~m}-80.0 \mathrm{~m}$ ) were selected at approximately even intervals from the mouth (most with similar substrate composition) to sample American eels. Location and selection of sampling sites were adjusted to maximize the inclusion of barriers and allow easy access (i.e., bridge access or permission from landowners). Sampling areas averaged $381 \mathrm{~m}^{2}$ and ranged from $87.5 \mathrm{~m}^{2}$ to $1,065.3 \mathrm{~m}^{2}$, depending upon stream width.

\section{Methods}

Sample and data collection.-Sampling sites were isolated with 5-mm-diameter nylon-mesh block nets and electrofished with a variable-voltage backpack shocker (Smith-Root) from June to August 2003 and 2004 to collect yellow-phase American eels. Reduction sampling (Kohler and Hubert 1999), three to five passes depending upon catch, was performed at each site. Eels were sedated with clove oil, counted, measured for total length (TL) and weight, and any obvious swellings, lesions, and ulcers were noted. Of 1,938 eels captured, a size-stratified random subsample, at each sampling site, of 232 eels was then collected. The number of eels collected for analysis at each sampling site was dependent on the total number of eels collected at the given sampling site and ranged from 1 (if only 1 eel was collected at that site) to 16 (if numerous eels were available). Selected eels were euthanized, placed on ice, and frozen for later dissection in the laboratory.
Sampling sites and all known barriers from the tributary's confluence with the Hudson River upstream to the point at which no American eels were collected were inventoried with a Garmin III Plus Global Positioning System device (WGS84). Barriers, either natural waterfalls or man-made structures (mill dams or water control structures) of at least $0.5 \mathrm{~m}$ in height were catalogued by type (natural or man-made) and measured for height.

In the laboratory, American eels were defrosted and rinsed of excess mucus, and their lengths and weights were remeasured. A subsample of 180 eels was then compared, which determined that freezing significantly reduced eel length and weight by $1.2 \%$ and $1.9 \%$, respectively $(P<0.01)$. All lengths, unless otherwise noted, are based on field measurements.

Otoliths were used to determine age structure in each tributary system. This procedure has been validated for American eels (Oliveira 1996). Methods for preparing and aging otoliths followed established methods (Secor et al. 1991; Graynoth 1999). Paired sagittal otoliths were removed from the eel, cleaned of excess material with a $10 \%$ bleach solution, and stored dry until later embedding in epoxy resin. Left and right otoliths were then randomly selected and thin sections were made in the transverse plane with twin-mounted diamond blades on an Isomet diamond saw. The section was then fixed to a slide with Crystalbond, ground to the core, and polished. Otoliths were etched and stained with $2 \%$ EDTA (buffered to a $\mathrm{pH}$ of approximately 8) and 5\% toluidine blue stain to produce thick, blue rings denoting annual growth. The glass eel transition mark (Michaud et al. 1988) was assumed to equal age 1 for all Hudson River eels (Mattes 1989; Morrison and Secor 2003). Age was determined by counting annual rings along multiple axes, at least one count being made along the left and right edge of the sulcal groove and one count being made along the long axis of the otolith (Figure 2). Age estimations were made on at least three separate occasions for each eel. Differences in age 


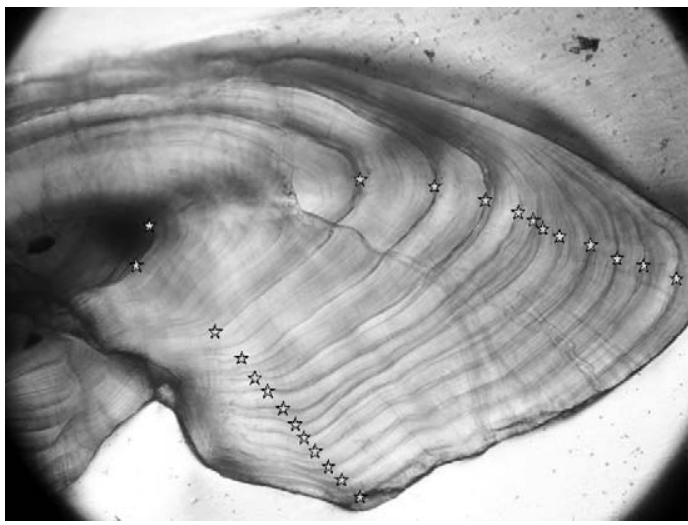

FIGURE 2.-Otolith from a yellow-phase American eel collected from the mouth of Saw Kill in 2003-2004. The stars designate annuli along two of the three transects (the right edge of the sulcal groove and the long axis) that were measured to estimate eel age. The third transect, the left edge of the sulcal groove, is off the image to the left. This $309-\mathrm{mm}$ American eel was 12 years old.

estimates between readers were discussed; if no solution was reached, the otolith was discounted from examination (four otoliths or $2 \%$ of all the otoliths read).

Gonads and connective tissue were removed from 102 American eels ranging from $205 \mathrm{~mm}$ to $710 \mathrm{~mm}$ $\mathrm{TL}$, which were soaked in $3 \%$ formalin for $48 \mathrm{~h}$ and stored in $70 \%$ ethanol before sexing. Gonads were classified (male versus female) following the squash method (Guerrero and Shelton 1974). For each eel, a small section of tissue was placed on a glass slide with a drop of acetocarmine stain. After $1 \mathrm{~min}$, the tissues were pressed with a cover glass and examined at $10 \times$ magnification with an image-capture system. Gonads were classified according to the descriptions of Beullens et al. (1997). Reference images of diagnostic structures were captured. Male gonads were typified by spermatogonium $b$ cells, while females were identified by presence of oocytes (Colombo and Grandi 1996).

Data analysis.-Estimates for standing stock at sampling sites were made with a binomial depletion model (BDM), a new Bayesian approach especially useful when population densities are low and that allows for the calculation of confidence intervals (Royle and Dorazio 2006; P. Sullivan, Cornell University, unpublished data). Two-factor analysis of variance (ANOVA) was used to test for differences in American eel density (as determined by the BDM), where tributaries and barriers were one series of treatments and barriers and distance upstream were another series of treatments.

We pooled American eels from all sampling sites to perform a stepwise linear regression to determine significant relationships between estimated eel abundances and the following tributary sampling site characteristics: (1) the number of barriers between a sampling site and the confluence of the tributary with the Hudson River (barriers); (2) the cumulative barrier height $(\mathrm{m})$ that must be surmounted to access each habitat sampled; (3) the distance of the sampling site from the mouth of the tributary; (4) the number of barriers per kilometer between a sampling site and the tributary's confluence with the main stem; (5) the proportion of channel urbanization at the sampling site; (6) the proportion of riparian urbanization at the sampling site; (7) the cumulative proportion of riparian urbanization upstream of the sampling location; (8) the proportion of subcatchment urbanization (as determined by ArcMap; ESRI 2004) for the sampling site; and (9) the proportion of urbanization within the entire watershed above the sampling site. Urbanization was determined through a GAP Analysis of land cover types for the six tributary watersheds using ArcMap geographical information systems (GIS) software (ESRI 2004).

An eel condition index was created through linear regression of log-transformed American eel TLs and observed weights $\left(\log _{e}[\right.$ weight $]=3.317 \cdot \log _{e}[$ length $]-$ 15.084; $r^{2}=0.99$ ), which met the assumptions of normality better than other condition factors, such as Fulton's condition factor ( $K$; Murphy and Willis 1996). Standardized residuals were calculated for each eel (Sokal and Rohlf 1995:174-175); thus, an eel with a value of +1 is one SD heavier than the average. Eels were then grouped to compare the effects of stream, urbanization, barrier influence, and a north-south gradient on eel condition index through ANOVA.

We clustered sampling sites into groups by (1) stream, (2) distance upstream from the confluence of the tributary with the Hudson River, (3) barrier, and (4) cumulative barrier height to test for differences between American eel lengths at age as determined from laboratory measurements of eel TLs through analysis of covariance (ANCOVA). All lengths and ages were $\log _{e}$ transformed to increase normality. The effect of barriers on eel condition and length at age was tested with a barrier intensity index (BII) that was defined as follows:

$$
\begin{aligned}
\mathrm{BII}= & \left(\frac{\text { number of barriers }}{\text { distance upstream }}\right) \\
& \times(\text { cumulative barrier height })^{2},
\end{aligned}
$$

where distance upstream is in kilometers and barrier height is in meters. This index would test the hypothesis that energy requirements and additional stresses incurred during passage around a barrier would 
have negative consequences on eel condition and growth. We chose to use a square term for cumulative barrier height to represent the nonlinear effect of this parameter as an energy cost to the eel.

Mean growth rates were estimated by dividing American eel TL (laboratory measurements) by the estimated age, assuming linear growth (Graynoth 1999; Morrison and Secor 2003), and were tested with ANOVA between eel size-class and barrier. Although Morrison and Secor (2003) accounted for oceanic growth before entry into the estuary by subtracting 1 year and $76.6 \mathrm{~mm}$ from length at age, we chose to use an oceanic growth of $66 \mathrm{~mm}$, given that we collected numerous partially pigmented elvers that were less than $76.6 \mathrm{~mm}$. Estimation of mean growth rates was therefore limited to estuary growth, tributary growth, or both.

For comparative purposes, we also computed von Bertalanffy growth parameters for all American eels, pooling across tributaries and sex. We did not have sufficient numbers of males and females to compute these parameters individually. The von Bertalanffy model for growth in length is

$$
L_{t}=L_{\infty}\left\{1-\exp \left[-K\left(t-t_{0}\right)\right]\right\},
$$

where $L_{t}$ is length $(\mathrm{mm})$ at age $t, L_{\infty}$ is asymptotic length, $K$ is the annual growth rate, and $t_{0}$ is an integration constant. We solved the parameters with a Levenberg-Marquardt nonlinear estimation algorithm (StatSoft 2003).

All statistical analyses were performed with the software STATISTICA (StatSoft 2003). An $\alpha$ level of 0.05 was used as a critical value to determine statistical significance.

\section{Results}

Thirty-one of 40 sampling sites had American eels, which ranged in TL from 50 to $850 \mathrm{~mm}$ (mean $=185$ $\mathrm{mm}$; median $=152 \mathrm{~mm})$. The 232 eels $(12 \%$ of all collected) that were analyzed in the laboratory ranged from $58 \mathrm{~mm}$ to $710 \mathrm{~mm}$ TL (mean $=259 \mathrm{~mm}$; median $=236 \mathrm{~mm}$ ). Of all eels captured, we collected $82.3 \%$ below the first barrier and $94.3 \%$ below the second barrier.

Within each stream, highest American eel densities were found near the mouth and below the first barrier; densities dropped dramatically beyond each barrier. Where eels were found, their densities varied greatly; the highest densities (155.1 eels/100 $\mathrm{m}^{2}$ ) occurred near the mouth of Hannacroix Creek and the lowest densities $\left(0.2\right.$ eels $\left./ 100 \mathrm{~m}^{2}\right)$ occurred at the third sampling site of Wynants Kill. This site was located approximately $0.9 \mathrm{~km}$ upstream from the confluence with the Hudson River and had four barriers that totaled $15.6 \mathrm{~m}$ in height between the sampling site and the Hudson River main stem (Table 2). Biomass varied from $0.3 \mathrm{~g} / 100 \mathrm{~m}^{2}$ (Wynants Kill; third site) to 2,363 g/ $100 \mathrm{~m}^{2}$ (near the mouth of Hannacroix Creek).

Although fewer American eels were caught in the Wynants Kill and Black Creek tributaries, ANOVA tests showed that there was no significant difference (df $=5, P=0.81)$ observed among whole-stream eel densities. Neither a north-south gradient nor a withinstream distance gradient were significant (north-south gradient: $\mathrm{df}=2, P=0.81$; within-stream gradient: $\mathrm{df}=$ $10, P=0.30$ ). However, the impact of barriers was significant $(\mathrm{df}=8, P<0.01)$, as sampling sites beyond the first barrier in a stream had significantly lower eel densities. Densities at sampling sites above the first barrier, separated by up to eight barriers, were not significantly different from one another $(\mathrm{df}=2, P=$ 0.12). Two-factor ANOVA of four tributaries (Hannacroix Creek, Saw Kill, Minisceongo Creek, and Peekskill Hollow Brook) showed no interaction between stream and barrier ( $\mathrm{df}=6, P=0.16)$.

Length frequencies for all of the American eels collected showed a preponderance of eels less than 150 $\mathrm{mm}$, which dominated sites near the mouths of streams (Figure 3). Length frequencies of eels collected above the second barrier were more normally distributed, ranging from $79 \mathrm{~mm}$ to $850 \mathrm{~mm}$. Eels had significantly longer TLs as distance upstream increased as well as beyond barriers $(P<0.01$; Figure 4$)$. Thus, as we sampled upstream, there was a general trend of fewer but larger eels and a decrease in overall eel biomass.

Stepwise linear regression produced a best fit estimate for American eel abundance at a given sampling location as

$$
\begin{aligned}
\log _{e}(\text { density })= & 25.166-2.730 \cdot \log _{e}(\text { barriers }) \\
& -0.165 \cdot \text { distance }+1.359 \cdot \text { SC_URB }
\end{aligned}
$$

$\left(r^{2}=0.63, P<0.001\right)$, where "barriers" is the number of barriers between the sampling site and the confluence of the tributary and the Hudson River, "distance" is the distance of the sample site from the mouth of the tributary $(<0.5,0.5-1.0,1.0-2.0,2.0$ $3.0,3.0-5.0,5.0-10.0,10.0-15.0,15.0-20.0$, or $>20.0$ $\mathrm{km}$ ), and SC_URB is the urbanization of the subcatchment sampling site determined by GAP Analysis in ArcMap (ESRI 2004).

American eel condition significantly decreased as urbanization of the riparian zone increased (ANOVA: df $=3, P<0.01$; Figure 5a). Similarly, as the BII increased, eel condition significantly decreased (ANOVA: df $=3, P<0.01$; Figure $5 \mathrm{~b}$ ). Eels that passed fewer than 0.5 barriers $/ \mathrm{km}$ had significantly better condition than eels that had to pass more than 0.5 barriers $/ \mathrm{km}$. 
TABLE 2.- Mean density and biomass of yellow-phase American eels sampled in tributaries of the Hudson River, $2003-2004$.

\begin{tabular}{|c|c|c|c|c|c|c|c|c|}
\hline Tributary & Site & $\begin{array}{c}\text { Eels } \\
\text { caught }\end{array}$ & Barriers $^{\mathrm{a}}$ & $\begin{array}{l}\text { Distance } \\
\text { upstream } \\
(\mathrm{m})^{\mathrm{b}}\end{array}$ & $\begin{array}{l}\text { Total length } \\
(\mathrm{mm})(\mathrm{SD})\end{array}$ & $\begin{array}{c}\text { Binomial } \\
\text { estimated density } \\
\left(\text { eels } / 100 \mathrm{~m}^{2}\right)\end{array}$ & $\begin{array}{l}\text { Binomial estimated } \\
\text { density }>300 \mathrm{~mm} \\
\left(\text { eels } / 100 \mathrm{~m}^{2}\right)\end{array}$ & $\begin{array}{c}\text { Estimated } \\
\text { biomass } \\
\left(\mathrm{g} / 100 \mathrm{~m}^{2}\right)^{\mathrm{c}}\end{array}$ \\
\hline \multirow[t]{7}{*}{ Wynants Kill } & 1 & 68 & 1 & 385 & $136.7(74.5)$ & 80.75 & 1.83 & 757.4 \\
\hline & 2 & 36 & 2 & 710 & $258.6(123.7)$ & 9.95 & 3.36 & 505.3 \\
\hline & 3 & 1 & 4 & 935 & 121.0 & 0.17 & 0 & 0.3 \\
\hline & 4 & 6 & 6 & 1,170 & $470.7(224.3)$ & 1.07 & 0.89 & 314.3 \\
\hline & 5 & 1 & 7 & 3,585 & 562.0 & 0.65 & 0.65 & 177.7 \\
\hline & 6 & 0 & 7 & 4,885 & & 0 & 0 & 0 \\
\hline & 7 & 0 & 7 & 7,090 & & 0 & 0 & 0 \\
\hline \multirow[t]{6}{*}{ Hannacroix Creek } & 1 & 387 & 0 & 740 & $168.6(83.0)$ & 155.06 & 5.46 & 2363.1 \\
\hline & 2 & 134 & 0 & 1,960 & $168.1(84.8)$ & 26.36 & 1.86 & 412.6 \\
\hline & 3 & 20 & 1 & 4,000 & 310.5 (196.3) & 1.43 & 0.56 & 167.7 \\
\hline & 4 & 9 & 3 & 13,720 & $352.3(142.6)$ & 4.11 & 2.74 & 436.9 \\
\hline & 5 & 13 & 3 & 17,910 & $363.6(189.8)$ & 4.60 & 2.50 & 688.4 \\
\hline & 6 & 0 & 5 & 31,330 & & 0 & 0 & 0 \\
\hline \multirow[t]{6}{*}{ Saw Kill } & 1 & 369 & 0 & 225 & $166.1(73.7)$ & 142.07 & 5.65 & 1782.9 \\
\hline & 2 & 23 & 1 & 335 & $287.0(117.9)$ & 10.09 & 3.86 & 581.0 \\
\hline & 3 & 0 & 2 & 485 & & 0 & 0 & 0 \\
\hline & 4 & 6 & 5 & 1,230 & $545.3(137.1)$ & 1.70 & 1.36 & 572.1 \\
\hline & 5 & 4 & 6 & 5,720 & $446.5(288.7)$ & 0.63 & 0.30 & 190.9 \\
\hline & 6 & 0 & 7 & 11,030 & & 0 & 0 & 0 \\
\hline \multirow[t]{7}{*}{ Black Creek } & 1 & 53 & 0 & 350 & $174.6(84.0)$ & 11.57 & 0.78 & 242.3 \\
\hline & 2 & 87 & 0 & 1,190 & $236.2(69.0)$ & 22.00 & 3.72 & 677.3 \\
\hline & 3 & 5 & 4 & 3,230 & $513.0(93.8)$ & 0.73 & 0.73 & 176.7 \\
\hline & 4 & 2 & 4 & 3,330 & $363.0(326.7)$ & 0.61 & 0.30 & 133.4 \\
\hline & 5 & 5 & 9 & 11,160 & $492.0(121.5)$ & 1.93 & 1.61 & 471.3 \\
\hline & 6 & 1 & 9 & 16,650 & & 0.28 & 0.28 & N/A \\
\hline & 7 & 0 & 9 & 27,325 & & 0 & 0 & 0 \\
\hline \multirow[t]{7}{*}{ Peekskill Hollow Brook } & 1 & 302 & 0 & 3,685 & $168.2(77.0)$ & 61.97 & 4.16 & 774.7 \\
\hline & 2 & 16 & 1 & 4,315 & $366.6(126.6)$ & 4.90 & 3.67 & 523.4 \\
\hline & 3 & 43 & 1 & 7,690 & $134.4(69.6)$ & 21.56 & 0.86 & 189.9 \\
\hline & 4 & 1 & 2 & 9,350 & 569.0 & 0.26 & 0.26 & 83.9 \\
\hline & 5 & 3 & 2 & 11,900 & $449.3(143.7)$ & 0.79 & 0.79 & 181.6 \\
\hline & 6 & 2 & 2 & 17,030 & $692.6(35.9)$ & 0.39 & 0.39 & 286.4 \\
\hline & 7 & 0 & 4 & 23,560 & & 0 & 0 & 0 \\
\hline \multirow[t]{7}{*}{ Minisceongo Creek } & 1 & 78 & 0 & 725 & $161.4(104.9)$ & 25.78 & 1.73 & 684.6 \\
\hline & 2 & 180 & 0 & 1,875 & $140.9(87.4)$ & 42.19 & 2.91 & 544.2 \\
\hline & 3 & 62 & 1 & 2,350 & $245.6(86.7)$ & 23.02 & 4.57 & 840.2 \\
\hline & 4 & 17 & 2 & 3,245 & $356.1(154.8)$ & 4.88 & 3.73 & 596.1 \\
\hline & 5 & 0 & 4 & 5,750 & & 0 & 0 & 0 \\
\hline & 6 & 3 & 4 & 5,805 & $287(223.0)$ & 0.91 & 0.29 & 86.8 \\
\hline & 7 & 0 & 5 & 8,940 & & 0 & 0 & 0 \\
\hline
\end{tabular}

${ }^{a}$ Number of barriers between the mouth of the tributary and the sampling site.

${ }^{\mathrm{b}}$ Distance upstream of the sampling site from the confluence of the tributary with the main stem of the Hudson River.

${ }^{\mathrm{c}}$ Biomass estimated from binomial depletion population estimates.

The 102 American eels larger than $200 \mathrm{~mm}$ that were sampled for sex determination consisted of 22 males, 70 females, and 10 undifferentiated eels. Females averaged $451.9 \mathrm{~mm}$ (range, $194-710 \mathrm{~mm}$ ) and had a mean age of 12.9 years (range, 4-24 years); males were smaller (mean length, $290.3 \mathrm{~mm}$; range, 206-360 mm) and, on average, younger (mean, 9.1 years; range, 3-16 years). In all sampled tributaries, the female : male ratio was 3.2:1, although below the first barrier of each tributary female : male distributions were more even at 1.1 females for every male. Above the first barrier, females dominated with an 8.8:1 female : male ratio. Of female eels, $76 \%$ were found above the first barrier in sampled tributaries, while $73 \%$ of identified males were below the first barrier and only $27 \%$ were above.

Estimated American eel ages were not significantly different among streams (Kruskal-Wallace rank test: $n$ $=226, \mathrm{df}=5, P=0.29$ ). When pooled, tributary stocks had mean ages of $6.4,6.6,9.0,8.2,6.8$, and 6.9 years along the north-south gradient of Wynants Kill, Hannacroix Creek, Saw Kill, Black Creek, Peekskill Hollow Brook, and Minisceongo Creek, respectively. The youngest eels collected were partially pigmented 


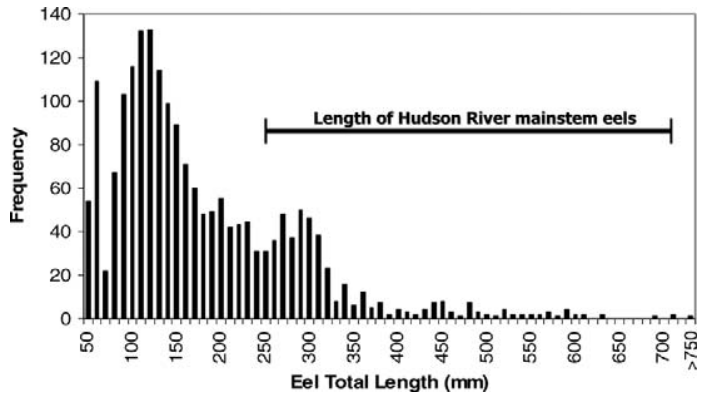

FIGURE 3.-Length-frequency distribution for yellow-phase American eels collected in the Hudson River estuary and six tributaries during 2003-2004. The horizontal bar denotes the size range of American eels collected in the Hudson River main stem during 1997-1999 (Morrison and Secor 2003). The skew of the size distribution toward smaller sizes suggests that tributaries are important nursery zones.

glass eels and recently transformed elvers in their first year of freshwater residency. The oldest eel, 24 years, was found at the first sampling site of Minisceongo Creek with a TL of $692 \mathrm{~mm}$ (note that one silver eel collected in Saw Kill, but not sacrificed, was over 850 $\mathrm{mm}$ and presumably of similar age or older). The oldest eels were distributed among streams and between sites above and below the first barrier of a tributary. There was a significant relationship between $\log _{e}(\mathrm{TL})$ and $\log _{e}$ (age) (Figure 6; $r^{2}=0.86 ; P<0.01$ ). Individual tributary length-at-age plots were more variable, but still significant $\left(r^{2}\right.$ range, $0.83-0.92 ; P<0.01$ for all tributaries). Grouping eels using the BII, we developed a length-at-age regression that showed significant differences in length at age among all three BII classes $\left(0,0.1-100\right.$, and $>100 ; r^{2}=0.90,0.85,0.76 ; P<0.01$; Figure 7).

The growth rates for tributary American eels ranged from 13 to $114 \mathrm{~mm} /$ year (mean, $35 \mathrm{~mm}$; median, 30 $\mathrm{mm}$ ); pooled within-tributary growth rates were higher in the northern and southern streams than in the central streams (Table 3). Analysis of variance showed that the eels within Wynants Kill (all of which were collected above the first barrier) and Peekskill Hollow Brook experienced significantly higher growth than those in other streams $(\mathrm{df}=5, P<0.01)$. Wynants Kill was the only tributary studied where all sampling sites were above at least one barrier. A two-factor ANOVA of growth rate that used five streams (Hannacroix Creek, Saw Kill, Black Creek, Peekskill Hollow Brook, and Minisceongo Creek) and sampling sites either above or below barriers as factors showed no significant difference in growth among streams and no interaction between streams and barriers (growth: $\mathrm{df}=4, P=0.06$;

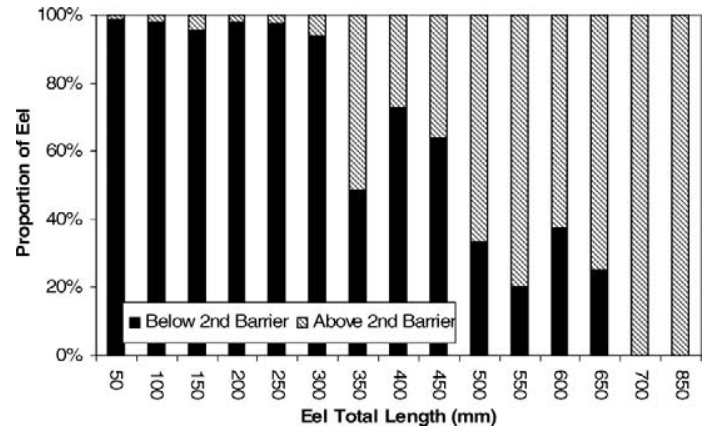

FIGURE 4.-Proportions of American eel size-classes found above and below the second barrier of censused Hudson River tributaries, 2003-2004. For example, of the 355 eels that were $50-99 \mathrm{~mm}$ in total length, $350(98.6 \%)$ were found below the second barrier and only 5 (1.4\%) beyond that barrier.

stream and barrier interaction: df $=4, P=0.87$ ). However, whether an eel was located above or below the first tributary barrier significantly affected growth rates $(\mathrm{df}=1, P<0.01$ ), eel growth being higher beyond the first barrier $(39.3 \mathrm{~mm} / \mathrm{year})$ than below the first barrier $(30.5 \mathrm{~mm} / \mathrm{year})$. There were no significant differences among eel growth rates between the first and ninth barriers ( $\mathrm{df}=6, P=0.68)$. Factorial ANOVA that tested eel growth by sex, barriers, and the interaction between sex and barriers showed that even though females exhibited slightly higher average growth $(35.3 \mathrm{~mm} / \mathrm{year})$ than males $(32.9 \mathrm{~mm} /$ year $)$, the difference was not significant $(\mathrm{df}=1, P=0.27)$. By sex, there was a significant difference between eel growth above or below the first tributary barrier $(\mathrm{df}=$ $1, P<0.01$ ), both male and female growth being higher beyond the first barrier in a tributary. Tukey honestly significant difference post hoc tests showed female eel growth below the first barrier was significantly different than female eel growth above the first barrier $(P<0.01)$ and male eel growth above the first barrier $(P=0.03)$.

Pooling all six tributaries, growth rates decreased with increasing age from age 2 (1 year oceanic stage and 1 year in freshwater; $56.7 \mathrm{~mm} /$ year) to ages $21-24$ (25.2 mm/year) in a nonlinear fashion. The von Bertalanffy growth equation had an overall $r^{2}$-value of $0.874(N=223)$. Asymptotic length $\left(L_{\infty}\right)$ was 929.1 $\pm 210.1 \mathrm{~mm}$ (mean $\pm \mathrm{SE}$ ), growth rate $K$ was 0.0404 $\pm 0.014 \mathrm{~mm} / \mathrm{year}$, and $t_{0}$ was $-1.431 \pm 0.48$; all parameters were highly significant $(P<0.01)$. Although similar data for American eels are sparse, Jessop et al. (2004) reported similar rates $(862.8 \mathrm{~mm}$, $0.04 \mathrm{~mm} /$ year, and -0.658 for $L_{\infty}, K$, and $t_{0}$, respectively) in female Nova Scotia American eels. 

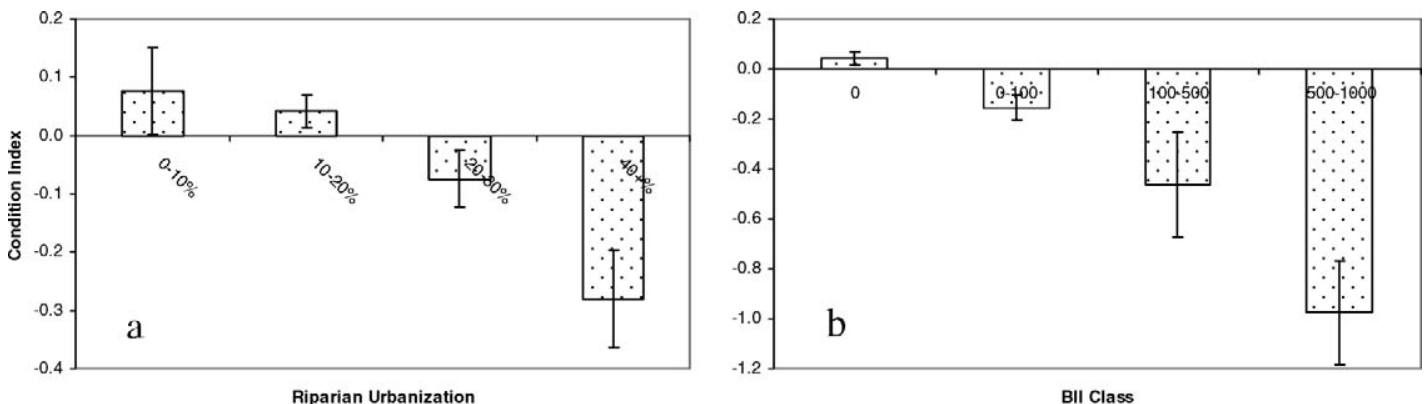

FIGURE 5.-Panel (a) shows the condition of yellow-phase American eels based on the mean standardized residuals of wet weight relative to the degree of riparian urbanization in Hudson River tributaries, 2003-2004. No eels were collected from sites with 30-40\% urbanization. Panel (b) shows eel condition relative to barrier intensity. The barrier intensity index (BII) reflects the compounding effects of both the number of barriers per kilometer and cumulative dam height. In both panels, negative values denote eels of lower than expected condition; error bars are SEs.

\section{Discussion}

In the moderately urbanized Hudson River estuary watershed, American eel demographic characteristics responded strongly to barriers (over half of which were artificial) and secondarily to local-scale urbanization in tributary subcatchments. Eel densities were highest below barriers, while age, growth (TL), and female : male sex ratios increased above barriers. Because the American eel is a top predator in Hudson River tributaries, upstream reduction of eel densities may increase the ecosystem's vulnerability to future human disturbances and further upset the natural food web there (e.g., Savoy and Crecco 2004).

Dams are among the most pervasive hydrological alterations of watersheds, and their environmental effects have been widely documented (e.g., McCully 1996; Humborg et al. 1997; Vörösmarty et al. 1997). The ecological consequences of stream fragmentation by dams include loss of biodiversity (Dudgeon 2000), alterations of productivity and nutrient fluxes (Humborg et al. 1997; Dauta et al. 1999) and, in particular, the dramatic impacts on diadromous fish species (confer Freeman et al. 2003). Although American eels do not contribute marine-derived nutrients to streams like many salmonids (i.e., Schindler et al. 2003) and some shads Alosa spp. (Garman and Macko 1998), they convey freshwater-derived production to the sea as they return to spawn (Laffaille et al. 2000). In our study, the increased segmentation of streams caused by dams appears to limit penetration of the Hudson River

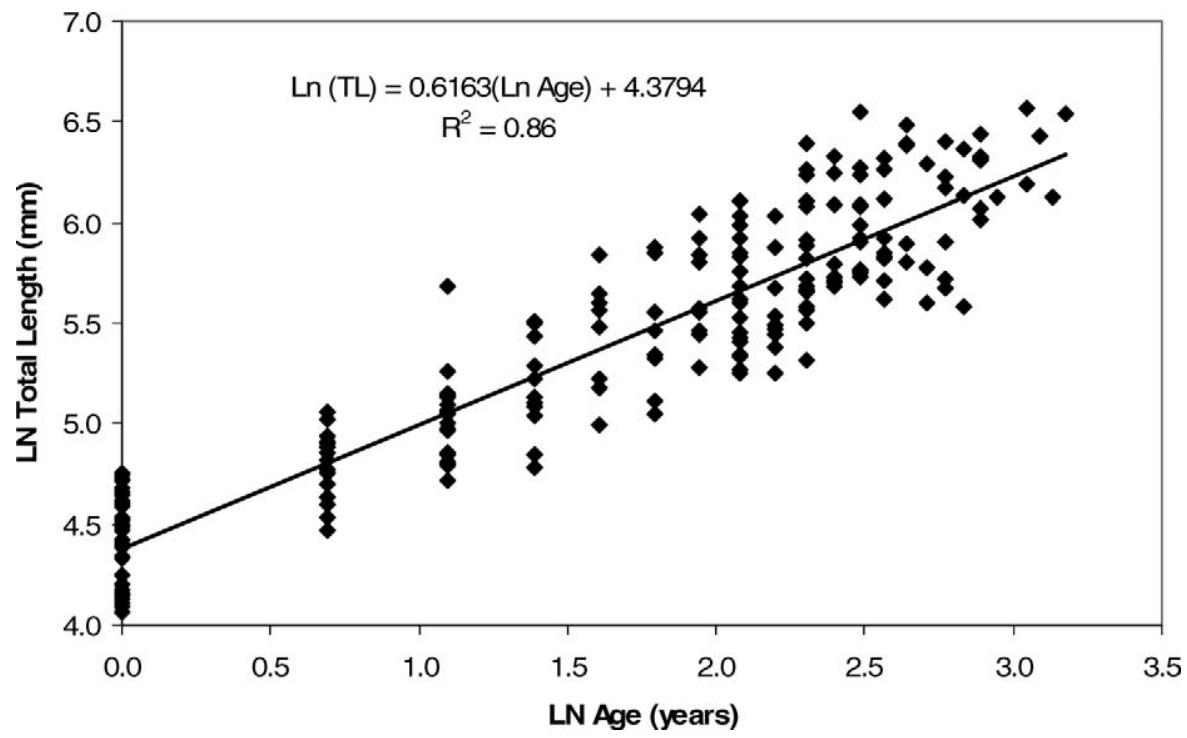

FIGURE 6.-Length of Hudson River tributary American eels versus age, 2003-2004. All values are $\log _{e}$ transformed (LN). 


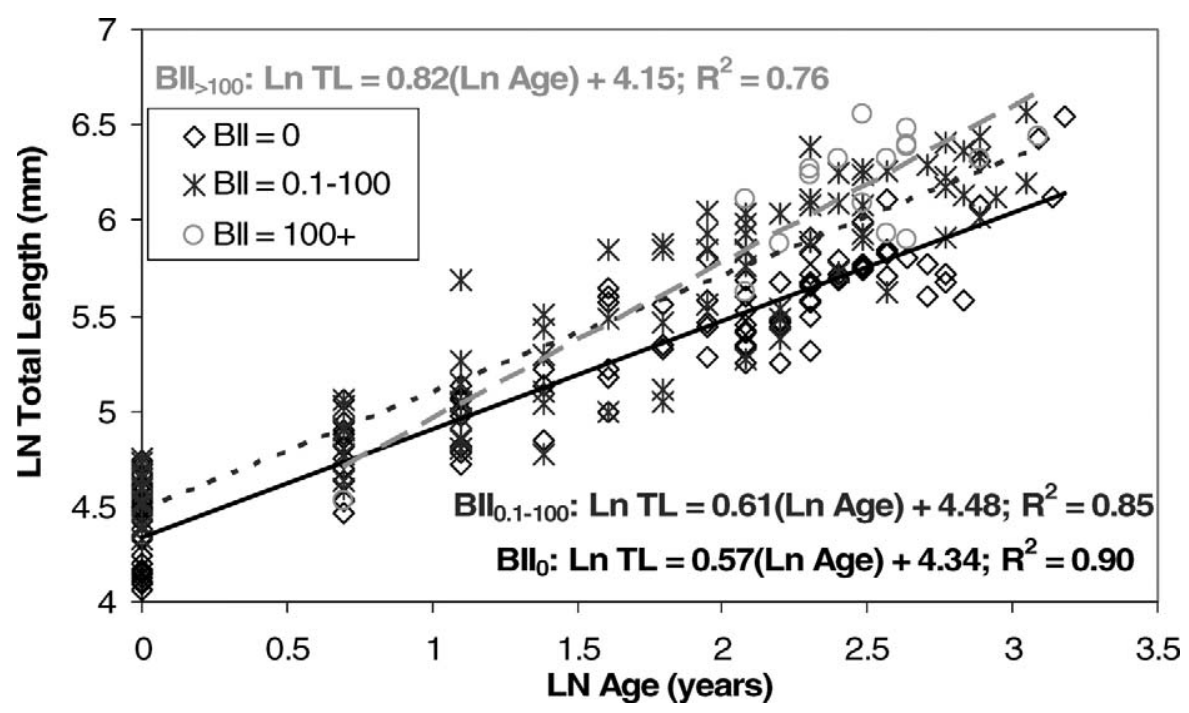

FIGURE 7.- - Length of Hudson River tributary American eels versus age by degree of barrier intensity (BII; see Figure 5 for details), 2003-2004. All values are $\log _{e}$ transformed. Eel growth is significantly lower below barriers $(P<0.01)$, suggesting that growth is density dependent ( $\mathrm{LN}=\log _{e}$ transformed).

watershed by eels. There are at least 797 large dams (generally $>3 \mathrm{~m}$ in height) in the watershed and an unknown, but suspected, high number of smaller dams (Swaney et al. 2006). The highest dam densities are in the downriver reaches of tributaries.

Nevertheless, with up to 155 American eels/100 $\mathrm{m}^{2}$ in the tributaries, eels were the most numerous fish within the Hudson River tributaries that we censused. Eels have been found to dominate both in distribution and numerically (Bozeman et al. 1985; Ford and Mercer 1986; Jacobs et al. 2004), and their dominance can drive ecosystem processes through structuring of the aquatic community (confer Eklöv and Hamrin 1989; Brabrand and Faafeng 1993; Dörner and Benndorf 2003). Eel densities are higher in unimpeded sections of Hudson River tributaries than has been previously reported in the literature (Table 4). Eel densities may be artificially increased within $0.5 \mathrm{~km}$ of a barrier owing to a congestion of eels blocked from upstream migration. While this may be responsible for densities found at the first Saw Kill sampling site and in Peekskill Hollow Brook (where the second site, located just above the first barrier, had a lower abundance estimate than the third site, located directly below the second barrier), habitat in these tributary reaches are conducive to high eel densities. Cobble and gravel substrates found at the third Peekskill Hollow Brook site, where smaller eels made up a greater proportion of the catch, offer extensive habitat not present at the second sampling site, which was composed of larger cobbles, boulders, and sand. Barrier proximity cannot explain high densities at the first Hannacroix Creek site since the first tributary barrier is more than $1.2 \mathrm{~km}$ upstream. The high densities, which are biased toward smaller size-classes near the mouths of tributaries, suggest that these areas are important to early eel life stages. The interstitial spaces, shallow water depth, and large invertebrate prey pool make these areas important to declining eel populations. Increased study of the contribution of

TABLE 3.- Pooled growth rates of Hudson River tributary American eels, 2003-2004.

\begin{tabular}{lcccccc}
\hline \multicolumn{1}{c}{ Tributary } & $\begin{array}{c}\text { Barrier } \\
\text { number }\end{array}$ & $\begin{array}{c}\text { Distance to } \\
\text { first barrier }(\mathrm{m})\end{array}$ & $\begin{array}{c}\text { Number of } \\
\text { eels aged }\end{array}$ & $\begin{array}{c}\text { Average growth } \\
\text { (mm/year) }\end{array}$ & SD & SE \\
\hline Wynants Kill & 7 & 20 & 17 & $45.4 \mathrm{z}$ & 21.42 & 5.20 \\
Hannacroix Creek & 4 & 1,985 & 31 & $34.2 \mathrm{y}$ & 16.04 & 2.88 \\
Saw Kill & 7 & 255 & 24 & $29.2 \mathrm{y}$ & 11.15 & 2.28 \\
Black Creek & 9 & 2,620 & 33 & $32.3 \mathrm{y}$ & 16.24 & 2.83 \\
Peekskill Hollow Brook & 4 & 3,825 & 27 & $42.8 \mathrm{z}$ & 18.63 & 3.59 \\
Minisceongo Creek & 6 & 1,900 & 39 & $33.9 \mathrm{y}$ & 13.90 & 2.23 \\
\hline
\end{tabular}

${ }^{\text {a }}$ Values with different letters are significantly different (single-factor ANOVA; $P<0.05$ ). 
TABLE 4.-Yellow-phase American eel density estimates from previous studies.

\begin{tabular}{lllrr}
\hline \multicolumn{1}{c}{ Location } & \multicolumn{1}{c}{ Authors } & Gear type & \multicolumn{1}{c}{$\begin{array}{c}\text { Density } \\
\left(\mathrm{eels} / 100 \mathrm{~m}^{2}\right)\end{array}$} & $\begin{array}{c}\text { Size } \\
\text { range (mm) }\end{array}$ \\
\hline Lake Champlain, Vermont & LaBar and Facey (1983) & Electrofishing & $2.32-6.36$ & N/A \\
Georgia tidal creek & Bozeman et al. (1985) & Eel pots & $1.82-2.32$ & $200-800$ \\
Massachusetts tidal creek & Ford and Mercer (1986) & Minnow trap & $8.46-9.28$ & $150-630$ \\
Rhode Island freshwater river & Oliveira (1997) & Electrofishing & $4.50-32.30$ & $>160$ \\
Four freshwater Maine rivers & Oliveira and McCleave (2000) & Electrofishing & $1.80-35.40$ & $>100$ \\
Hudson River shoals, New York & Morrison and Secor (2003) & Eel pots & $0.03-0.24$ & $280-700$ \\
Hudson River tributaries & This study & Electrofishing & $0.28-155.06$ & $60-850$ \\
\hline
\end{tabular}

tributary habitats versus main-stem habitat is warranted to quantify the relative importance of these different zones as juvenile rearing areas.

Full utilization of tributary habitat was limited, however, by the number of barriers that inhibit American eel distribution. The first barriers encountered dramatically reduced eel densities and disrupted migration into suitable upstream eel habitat. Historical records have shown sustained commercial eel catches hundreds of kilometers inland in Onondaga and Oneida lakes (Beauchamp 1908; Adams and Hankinson 1928) before damming obstructed immigration and emigration routes. Competition at the mouth may be reduced and eel condition may be increased if more eels were allowed farther upstream in tributaries (i.e., passes beyond the barrier should be established). Barriers may not have played an important role in eel distribution in the Annaquatucket River, Rhode Island (Oliveira 1997), because of the presence of fish passage structures on downstream barriers. Gephard and McMenemy (2004) also noted the importance of fish passage structures in reducing the impact of barriers to eel movement. It is important to note that not all barrier passage systems will be equally functional for migrating eels. Primarily, barrier passage structures designed in the U.S. are developed for fast-swimming fishes (i.e., Alosa spp. and salmonids; Lenhart 2003). Eels, with a different swimming style and slower speed, may have difficulty using these structures and may benefit from differing barrier passage designs (Knights and White 1998; Stuart and Mallen-Cooper 1999; Tesch 2003).

Barriers were the dominant factor in predicting American eel abundances in our regression model. The relationship of upstream distance to eel density has been well documented in American eel (Smogor et al. 1995; Krueger and Oliveira 1999; Oliveira and McCleave 2000). Barriers were determined to be of minor influence, secondary to distance upstream, in determining American eel distribution in the Potomac River drainage (Goodwin and Angermeier 2003). In tributaries of the Hudson River watershed, barrier impacts probably play a greater role in eel distribution, given the large number of barriers found within relatively short distances in study tributaries (e.g., there were seven barriers within the first $1.5 \mathrm{~km}$ of Wynants Kill). The first barrier in five of six tributaries was within $2.5 \mathrm{~km}$ of the tributary mouth, and two of the six streams had barriers less than $0.5 \mathrm{~km}$ from the mouth.

Barriers may also negatively affect American eel condition by disrupting eel behavior. Eels have been found to migrate between habitat types (Morrison and Secor 2003; Daverat et al. 2006), and it has been suggested that barriers hamper normal eel movements between habitats (Cairns et al. 2004). Svedäng and Wickström (1997) suggested that eels with low fat content (lower condition) temporarily arrest maturation during their initial spawning phase to feed and increase body mass (fat content) sufficient to reach spawning grounds. Morrison et al. (2003) noted that eels that had migrated from fresh to brackish water exhibited increased growth. Eels historically may have moved upstream to reduce competition and increase TL, moving downstream at later stages to increase fat content necessary to successfully reach the Sargasso spawning grounds. Placement of barriers in these tributaries may negatively affect this life history trait.

High densities below the first barrier caused by interruptions to upstream migration might increase competition, reduce food availability, and thus negatively affect growth rate (Graynoth and Taylor 2000, 2004; Beentjes and Jellyman 2003). Food supply may also play an important role if barriers alter aquatic invertebrate prey densities (Cortes et al. 1998).

Urbanization of tributary watersheds poses a second potential stressor. While there is an apparent positive effect of subcatchment urbanization on American eel distribution, this may be an artifact of sampling. Areas of high eel density, which are near the confluence of tributaries with the Hudson River, are also sites of historic human development. Historically a major commercial conduit, many towns developed along the Hudson River are causing unequal development within the watershed (i.e., near the main stem in areas of naturally high eel density). Therefore, higher eel 
densities may coincide with urbanization but may not be directly linked to urban densities. Further research is needed to determine potential direct or indirect effects of urbanization on eel density and eel distribution, as negative effects of urbanization have been found in other watersheds (Limburg and Schmidt 1990; Wang et al. 1997; Coghlan and Ringler 2005; Limburg et al. 2005). Changes in the riparian zone may affect shading, allochthonous inputs, hydrology, and water chemistry by altering stream geomorphology, water quality, and invertebrate prey densities (Growns et al. 1998; Wolter et al. 2000; Paul and Meyer 2001). Changes in riparian zone land use have been found to alter macroinvertebrate composition (Lenat and Crawford 1994; Moore and Palmer 2005), which may modify prey densities and reduce eel condition. Influences of urbanization may be unequal, however. Changes in stream flow that create larger interstitial spaces may increase eel density if the eel can survive sublethal increases in eutrophication or pollution caused by urbanization.

However, there may be a threshold at which American eel density and condition are negatively affected by extensive urbanization of the tributary watershed. Within the Wynants Kill watershed, GAP Analysis showed approximately 70\% urbanization of the subcatchment, and we noted high stream and streambank degradation and potential sources of pollution (litter and chemicals). Eels were only found within the lowest $5 \mathrm{~km}$ of the tributary and were of dramatically lower condition. Higher parasite loads of Eustrongylides and Anguillicola crassus were found in the highly urbanized sites of Wynants Kill and Minisceongo Creek (Machut 2006). Given the declining population estimates for eels, a greater understanding of the impacts of riparian zones on eel condition and on small-stream ecology is generally needed. Management policies to protect riparian zones from development are warranted.

While barriers and human-dominated land uses shift tributary American eel demographics, comparisons between the sampling streams and the Hudson River main stem suggest that tributaries are still an important component of yellow-phase eel habitat. Comparisons with the main stem must take into account the greater range of eel sizes collected during this study. Direct comparisons of main-stem and tributary stocks are possible via size-corrected density estimates. Hudson River density estimates (Morrison and Secor 2004) assumed unbiased capture of eels larger than $300 \mathrm{~mm}$; therefore, eel abundance estimates between main-stem and tributary stocks can be made if only eels greater than $300 \mathrm{~mm}$ TL are compared (Table 2). It is evident that the densities found in the distant upper reaches of the tributaries are comparable to Hudson River abundance estimates and are on average two orders of magnitude higher near the mouths of the tributaries. Given this, tributary abundances seem to be an important component of watershed populations, given their highly suitable additional habitat range and protection from predation. Eel predators in larger estuary waters (Buckel and Conover 1997; Griffin and Margraf 2003; Walter and Austin 2003) are rarely found in tributaries. Tributary eels can be an important component of the silver-phase spawning runs from the Hudson River. With increased access to upstream habitat, tributaries may play a significant role in providing refuge and enhanced yellow-phase growth opportunities to threatened eel stocks. Morrison and Secor (2004) noted that eel abundances in the Hudson River were lower than the commercial catches in both the Delaware and Chesapeake Bay estuaries and suggested that this was caused by the lower carrying capacity for the Hudson River. Enhancing tributary habitat may increase the carrying capacity of the entire watershed.

The mean lifetime growth rates for pooled Hudson River tributary American eels larger than $300 \mathrm{~mm}$ (as calculated through otolith aging) are comparable with growth estimates developed for the freshwater Hudson River main stem (Morrison and Secor 2003). While growth above barriers within tributaries is greater than that found in the freshwater sections of the Hudson River, it is still lower than the estimated brackish-water growth rates in the Hudson River main stem (Morrison and Secor 2003). The growth rates above barriers are also greater than those reported in Maine rivers and a Rhode Island stream (Oliveira 1997; Oliveira and McCleave 2000), but are lower than found in southern systems (Helfman et al. 1984). This suggests that tributary eel stocks can be a significant source of eel production for the entire Hudson River estuary.

Increased length at age above barriers may also be coupled with sexual differences in growth rate (Poole and Reynolds 1996; Oliveira and McCleave 2000). Oliveira (1997) also found American eels having TLs greater than $400 \mathrm{~mm}$ (presumed females) in a Rhode Island river grew significantly faster than eels less than $400 \mathrm{~mm}$ (presumed males or undifferentiated). In our study tributaries, female eels did not grow at rates different from those of males, but they exhibited increased growth above barriers. The results from the two-factor ANOVA test (growth by sex and barrier) suggest that density-dependent factors play a more important role than sex in growth. Both eel sexes had higher growth rates beyond the first barrier than below the first barrier, where densities were increased by a factor of ten. This suggests that density-dependent 
factors (such as food availability) exert the greatest control over growth rate.

Reducing barrier impacts, such as within Wynants Kill, where there are a number of dams with questionable function, could further increase American eel use of Hudson River tributaries. Reductions in barriers or increased ease of passage would also reduce the impact of barriers on eels currently residing in the tributaries, potentially increasing eel condition and growth below barriers. Female eel size is positively correlated with increased fecundity (Barbin and McCleave 1997); therefore, increasing eel condition in tributaries may help to stabilize decreasing American eel populations and increase recruitment. Additionally, increased tributary access throughout the species' range may provide refuges from exploitation in other basins. Although reducing barrier impact through eel ladders or removal of dams with minimal value will not return the affected tributaries to their prior state (Scheffer and Carpenter 2003), increased passage of eels would reduce current anthropogenic impacts. Given the apparent drastic decline in eel abundances from certain portions of their historic range, increasing available habitat for eels and minimizing human disturbances upon tributaries, in general, is a worthy and attainable goal.

\section{Acknowledgments}

We thank R. McDonald for help in creating Figure 1 and, together with R. Butryn, for invaluable help with the GIS analysis. We also thank J. Anderson, E. Leibu, A. Lang, N. Akpan, P. Simonin, A. Sopacua, and N. Karraker for field and laboratory assistance. The project was supported by the Hudson River Foundation and NSF DEB-0238121. Reference to trade names does not imply endorsement by the U.S. Government.

\section{References}

Adams, C. C., and T. L. Hankinson. 1928. The ecology and economics of Oneida Lake fish. New York State College of Forestry Roosevelt Wild Life Annals 1:235-548.

ASMFC (Atlantic States Marine Fisheries Commission). 2000. Interstate fishery management plan for the American eel. ASMFC, Fishery Management Report 36, Washington, D.C.

ASMFC (Atlantic States Marine Fisheries Commission). 2006. Review of the Atlantic States Marine Fisheries Commission fishery management plan for American eel (Anguilla rostrata). ASMFC, Washington, D.C

Barbin, G. P., and J. D. McCleave. 1997. Fecundity of the American eel Anguilla rostrata at $45^{\circ} \mathrm{N}$ in Maine, USA Journal of Fish Biology 51:840-847.

Beauchamp, W. M. 1908. Past and present of Syracuse and Onondaga County, New York. S. J. Clarke, New York.

Beentjes, M. P., and D. J. Jellyman. 2003. Enhanced growth of longfin eels, Anguilla dieffenbachii, transplanted into
Lake Hawea, a high-country lake in South Island, New Zealand. New Zealand Journal of Marine and Freshwater Research 37:1-11.

Beullens, K., E. H. Eding, P. Gilson, F. Ollevier, J. Korman, and C. J. J. Richer. 1997. Gonadal differentiation, intersexuality, and sex ratios of European eel (Anguilla anguilla L.) maintained in captivity. Aquaculture 153:135-150.

Bozeman, E. L., G. S. Helfman, and T. Richardson. 1985. Population size and home range of American eels in a Georgia tidal creek. Transactions of the American Fisheries Society 114:821-825.

Brabrand, Å., and B. Faafeng. 1993. Habitat shift in roach (Rutilus rutilus) induced by pikeperch (Stizostedion lucioperca) introduction: predation risk versus pelagic behaviour. Oecologia 95:38-46.

Buckel, J. A., and D. O. Conover. 1997. Movements, feeding periods, and the daily ration of piscivorous young-of-theyear bluefish, Pomatomus saltatrix, in the Hudson River estuary. U.S. National Marine Fisheries Service Fishery Bulletin 95:665-679.

Busch, W. D. N., S. J. Lary, C. M. Castilione, and R. P. McDonald. 1998. Distribution and availability of Atlantic coast freshwater habitats for American eel (Anguilla rostrata). U.S. Fish and Wildlife Service, Administrative Report 98-2, Amherst, New York.

Cairns, D. K., J. C. Shiao, Y. Iizuka, W. N. Tzeng, and C. D. MacPherson. 2004. Movement patterns of American eels in an impounded watercourse, as indicated by otolith microchemistry. North American Journal of Fisheries Management 24:452-458.

Castonguay, M., P. V. Hodson, C. M. Couillard, M. J. Eckersley, J. D. Dutil, and G. Verreault. 1994. Why is recruitment of the American eel, Anguilla rostrata, declining in the St. Lawrence River and Gulf? Canadian Journal of Fisheries and Aquatic Sciences 51:479-488.

Coghlan, S. M., and N. H. Ringler. 2005. Survival and bioenergetic responses of juvenile Atlantic salmon along a perturbation gradient in a natural stream. Ecology of Freshwater Fishes 14:111-124.

Colombo, G., and G. Grandi. 1996. Histological study of the development and sex differentiation of the gonad in the European eel. Journal of Fish Biology 48:493-512.

Cortes, R. M. V., M. T. Ferreira, S. V. Oliveira, and F. Godinho. 1998. Contrasting impact of small dams on the macroinvertebrates of two Iberian mountain rivers. Hydrobiologia 389:51-61.

Dauta, A., Y. Lapaquellerie, and N. Maillet. 1999. Role of the dams on the River Lot on two types of pollution: point sources (cadmium) and non-point sources (phosphorus). Hydrobiologia 410:325-329.

Daverat, F., K. E. Limburg, I. Thibault, J. C. Shiao, J. J. Dodson, F. Caron, W.-N. Tzeng, Y. Iizuka, and H. Wickström. 2006. Phenotypic plasticity of habitat use by three temperate eel species, Anguilla anguilla, A. japonica, and A. rostrata. Marine Ecology Progress Series 308:231-241.

Dörner, H., and J. Benndorf. 2003. Piscivory by large eels on young-of-the-year fishes: its potential as a biomanipulation tool. Journal of Fish Biology 62:491-494.

Dudgeon, D. 2000. Large-scale hydrological changes in 
tropical Asia: prospects for riverine biodiversity. BioScience 50:793-806.

Eklöv, P., and S. F. Hamrin. 1989. Predatory efficiency and prey selection: interactions between pike Esox lucius, perch Perca fluviatilis, and rudd Scardinus erythrophthalmus. Oikos 56:149-156.

ESRI (Environmental Systems Research Institute, Inc.) 2004. ArcGIS, version 9. ESRI, Redlands, California. Available: www.esri.com. (Septemeber 2005).

Feunteun, E. 2002. Management and restoration of European eel population (Anguilla anguilla): an impossible bargain. Ecological Engineering 18:579-591.

Ford, T. M., and E. Mercer. 1986. Density, size distribution, and home range of American eels, Anguilla rostrata, in a Massachusetts salt marsh. Environmental Biology of Fishes 17:309-314.

Freeman, M. C., C. M. Pringle, E. A. Greathouse, and B. J. Freeman. 2003. Ecosystem-level consequences of migratory faunal depletion caused by dams. Pages 255-266 in K. E. Limburg and J. R. Waldman, editors. Biodiversity, status, and conservation of shads worldwide. American Fisheries Society, Symposium 35, Bethesda, Maryland.

Garman, G. C., and S. A. Macko. 1998. Contribution of marine-derived organic matter to an Atlantic coast, freshwater, tidal stream by anadromous clupeid fishes. Journal of the North American Benthological Society 17:277-285.

Gephard, S., and J. McMenemy. 2004. An overview of the program to restore Atlantic salmon and other anadromous fishes to the Connecticut River, with notes on the current status of these species in the river. Pages 287-317 in P. M. Jacobson, D. A. Dixon, W. C. Leggett, B. C. Marcy, Jr., and R. R. Massengill, editors. The Connecticut River ecological study (1965-1973) revisited: ecology of the lower Connecticut River, 1973-2003. American Fisheries Society, Monograph 9, Bethesda, Maryland.

Goodwin, K. R., and P. L. Angermeier. 2003. Demographic characteristics of American eel in the Potomac River drainage, Virginia. Transactions of the American Fisheries Society 132:524-535.

Graynoth, E. 1999. Improved otolith preparation, aging, and back-calculation techniques for New Zealand freshwater eels. Fisheries Research 42:137-146.

Graynoth, E., and M. Taylor. 2000. Influence of different rations and water temperature on the growth rates of shortfinned eels and longfinned eels. Journal of Fish Biology 57:681-699.

Graynoth, E., and M. Taylor. 2004. Growth of juvenile eels (Anguilla spp.) in lowland streams in New Zealand. Fisheries Research 66:95-106.

Griffin, J. C., and F. J. Margraf. 2003. The diet of Chesapeake Bay striped bass in the late 1950s. Fisheries Management and Ecology 10:323-328.

Growns, I. O., D. A. Pollard, and P. C. Gehrke. 1998. Changes in river fish assemblages associated with vegetated and degraded banks upstream of and within nutrient-enriched zones. Fisheries Management and Ecology 5:55-69.

Guerrero, R. D., III, and W. L. Shelton. 1974. An acetocarmine squash method for sexing juvenile fishes. Progressive Fish-Culturist 36:56.

Haro, A. J., and W. H. Krueger. 1991. Pigmentation, otolith rings, and upstream migration of juvenile American eels (Anguilla rostrata) in a coastal Rhode Island stream. Canadian Journal of Zoology 69:812-814.

Haro, A. J., W. Richkus, K. Whalen, A. Hoar, W. D. Busch, S. Lary, T. Brush, and D. Dixon. 2000. Population decline of the American eel: implications for research and management. Fisheries 25(9):7-16.

Helfman, G. S., E. L. Bozeman, and E. B. Brothers. 1984. Size, age, and sex of American eels in a Georgia River. Transactions of the American Fisheries Society 113:132141.

Helfman, G. S., D. E. Facey, L. S. Hales, Jr., and E. L. Bozeman, Jr. 1987. Reproductive ecology of the American eel. Pages 42-56 in M. J. Dadswell, R. J. Klauda, C. M. Moffitt, R. L. Saunders, R. A. Rulifson, and J. E. Cooper, editors. Common strategies of anadromous and catadromous fishes. American Fisheries Society, Symposium 1, Bethesda, Maryland.

Humborg, C., V. Ittekkot, A. Cociasu, and B. Bodungen. 1997. Effect of Danube River dam on Black Sea biogeochemistry and ecosystem structure. Nature (London) 386:385-388.

ICES (International Council for the Exploration of the Sea). 2004. Report of the ICES/EIFAC Working Group on eels. International Council for the Exploration of the Sea, C.M. 2004/ACFM:09, Copenhagen.

Jacobs, R. P., W. A. Hyatt, N. T. Hagstrom, E. B. O’Donnell, E. C. Schluntz, P. Howell, and D. R. Molnar. 2004. Trends in abundance, distribution, and growth of freshwater fishes from the Connecticut River in Connecticut (1988-2002). Pages 319-343 in P. M. Jacobson, D. A. Dixon, W. C. Leggett, B. C. Marcy, Jr., and R. R. Massengill, editors. The Connecticut River ecological study (1965-1973) revisited: ecology of the lower Connecticut River, 1973-2003. American Fisheries Society, Monograph 9, Bethesda, Maryland.

Jellyman, D. J. 1977. Summer upstream migration of juvenile freshwater eels in New Zealand. New Zealand Journal of Marine and Freshwater Research 11:61-71.

Jessop, B. 1987. Migrating American eels in Nova Scotia. Transactions of the American Fisheries Society 116:161170.

Jessop, B. M., J. C. Shiao, Y. Iizuka, and W. N. Tzeng. 2004. Variation in the annual growth, by sex and migration history, of silver American eels Anguilla rostrata. Marine Ecology Progress Series 272:231-244.

Kahn, J. R., and R. B. Buerger. 1994. Valuation and the consequences of multiple sources of environmental deterioration: the case of the New York State striped bass fishery. Journal of Environmental Management 40:257-273.

Knights, B., and E. M. White. 1998. Enhancing immigration and recruitment of eels: the use of passes and associated trapping systems. Fisheries Management and Ecology 5:459-471.

Kohler, C. C., and W. A. Hubert, editors. 1999. Inland fisheries management in North America, 2nd edition. American Fisheries Society, Bethesda, Maryland.

Krueger, W. H., and K. Oliveira. 1999. Evidence for environmental sex determination in the American eel, Anguilla rostrata. Environmental Biology of Fishes 53:381-389. 
LaBar, G. W., and D. E. Facey. 1983. Local movements and inshore population sizes of American eels in Lake Champlain, Vermont. Transactions of the American Fisheries Society 112:111-116.

Laffaille, F., E. Feunteun, A. Acou, and J. C. Lefeuvre. 2000. Role of European eel (Anguilla anguilla L.) in the transfer of organic matter between marine and freshwater systems. Internationale Vereinigung für Theoretische und Angewandte Limnologie Verhandlungen 27:616-619.

Legault, A. 1988. Le franchissement des barrages par l'escalade de l'anguille: étude en Sèvre Niortaise. [Passing dams by climbing in eels: a study in Sèvre Niortaise.] Bulletin Français de la Pêche et de la Pisciculture 308:1-10.

Lenat, D. R., and J. K. Crawford. 1994. Effects of land use on water quality and aquatic biota of three North Carolina piedmont streams. Hydrobiologia 294:185-199.

Lenhart, C. F. 2003. A preliminary review of NOAA's community-based dam removal and fish passage projects. Coastal Management 31:79-98.

Limburg, K. E., K. A. Hattala, and A. W. Kahnle. 2003. American shad in its native range. Pages 125-140 in K. E. Limburg and J. R. Waldman, editors. Biodiversity, status, and conservation of shads worldwide. American Fisheries Society, Symposium 35, Bethesda, Maryland.

Limburg, K. E., and R. E. Schmidt. 1990. Patterns of fish spawning in Hudson River tributaries: response to an urban gradient? Ecology 71:1238-1245.

Limburg, K. E., K. M. Stainbrook, J. D. Erickson, and J. M. Gowdy. 2005. Urbanization consequences: case studies in the Hudson River watershed. Pages 23-37 in L. R. Brown, R. H. Gray, R. M. Hughes, and M. Meador, editors. The effects of urbanization on aquatic ecosystems. American Fisheries Society, Symposium 47, Bethesda, Maryland.

Machut, L. S. 2006. Population dynamics, Anguillicola crassus infection, and feeding selectivity of American eel (Anguilla rostrata) in tributaries of the Hudson River, New York. Master's thesis. SUNY College of Environmental Science and Forestry, Syracuse, New York.

Mattes, K. C. 1989. The ecology of American eel, Anguilla rostrata L., in the Hudson River. Doctoral dissertation. Fordham University, New York.

McCully, P. 1996. Silenced rivers: the ecology and politics of large dams. Zed Books, London.

McGrath, K. J., D. Desrochers, and C. Fluery. and J. W. Dembeck IV. 2003. Studies of upstream migrant American eels at the Moses-Saunders Power Dam on the St. Lawrence River near Massena, New York. Pages 153-166 in D. A. Dixon, editor. Biology, management, and protection of catadromous eels. American Fisheries Society, Symposium 33, Bethesda, Maryland.

Michaud, M., J. D. Dutil, and J. J. Dodson. 1988 Determination of the age of young American eels, Anguilla rostrata, in freshwater based on otolith surface area and microstructure. Journal of Fish Biology 32:179_ 189.

Moore, A. A., and M. A. Palmer. 2005. Invertebrate biodiversity in agricultural and urban headwater streams: implications for conservation and management. Ecological Applications 15:1169-1177.

Morrison, W. E., and D. H. Secor. 2003. Demographic attributes of yellow-phase American eel (Anguilla rostrata) in the Hudson River estuary. Canadian Journal of Fisheries and Aquatic Sciences 60:1487-1501.

Morrison, W. E., and D. Secor. 2004. Abundance of yellowphase American eels in the Hudson River estuary. Transactions of the American Fisheries Society 133:896-910.

Morrison, W. E., D. H. Secor, and P. M. Piccoli. 2003. Estuarine habitat use by Hudson River American eels as determined by otolith strontium : calcium ratios. Pages 87-99 in D. A. Dixon, editor. Biology, management, and protection of catadromous eels. American Fisheries Society, Symposium 33, Bethesda, Maryland.

Murphy, B. R., and D. W. Willis, editors. 1996. Fisheries techniques, 2nd edition. American Fisheries Society, Bethesda, Maryland.

NMFS (National Marine Fisheries Service). 2005. Annual commercial landing statistics. Available: www.st.nmfs. noaa.gov/st1/commercial/landings/annual_landings.html. (August 2005).

Oliveira, K. 1996. Field validation of annular growth rings in the American eel, Anguilla rostrata, using tetracyclinemarked otoliths. U.S. National Marine Fisheries Service Fishery Bulletin 94:186-189.

Oliveira, K. 1997. Movements and growth rates of yellowphase American eels in the Annaquatucket River, Rhode Island. Transactions of the American Fisheries Society 126:638-646.

Oliveira, K., and J. D. McCleave. 2000. Variation in population and life history traits of the American eel, Anguilla rostrata, in four rivers in Maine. Environmental Biology of Fishes 59:141-151

Paul, M. J., and J. L. Meyer. 2001. Streams in the urban landscape. Annual Review of Ecology and Systematics $32: 333-365$

Poole, W. R., and J. D. Reynolds. 1996. Growth rate and age at migration of Anguilla anguilla. Journal of Fish Biology 48:633-642.

Richkus, W., and K. Whalen. 1999. American eel (Anguilla rostrata) scoping study: a literature and data review of life history, stock status, population dynamics, and hydroelectric impacts. Electric Power Research Institute, TR-111873, Palo Alto, California.

Royle, J. A., and R. M. Dorazio. 2006. Hierarchical models of animal abundance and occurrence. Journal of Agricultural Biological and Environmental Statistics 11:249263.

Savoy, T. F., and V. A. Crecco. 2004. Factors affecting the recent decline of blueback herring and American shad in the Connecticut River. Pages 361-377 in P. M. Jacobson, D. A. Dixon, W. C. Leggett, B. C. Marcy, Jr., and R. R. Massengill, editors. The Connecticut River ecological study (1965-1973) revisited: ecology of the lower Connecticut River, 1973-2003. American Fisheries Society, Monograph 9, Bethesda, Maryland.

Scheffer, M., and S. R. Carpenter. 2003. Catastrophic regime shifts in ecosystems: linking theory to observation. Trends in Ecology and Evolution 18:648-656.

Schindler, D. E., M. D. Scheuerell, J. W. Moore, S. M. Gende, T. B. Francis, and W. J. Palena. 2003. Pacific salmon and the ecology of coastal ecosystems. Frontiers in Ecology and the Environment 1:31-37. 
Schmidt, R. E., B. Jessop, and J. Hightower. 2003. Status of river herring stocks in large rivers. Pages 171-182 in K. E. Limburg and J. R. Waldman, editors. Biodiversity, status, and conservation of the world's shads. American Fisheries Society, Symposium 35, Bethesda, Maryland.

Secor, D. H., J. M. Dean, and E. H. Laban. 1991. Manual for otolith removal and preparation for microstructure analysis. University of South Carolina Press, Columbia.

Smith, T. I. J., and J. P. Clugston. 1997. Status and management of Atlantic sturgeon, Acipenser oxyrinchus, in North America. Environmental Biology of Fishes 48:335-346.

Smogor, R. A., P. L. Angermeier, and C. K. Gaylord. 1995. Distribution and abundance of American eels in Virginia streams: tests of null models across spatial scales. Transactions of the American Fisheries Society 124:789-803.

Sokal, R. R., and F. J. Rohlf. 1995. Biometry: the principles and practices of statistics in biological research. Freeman, New York.

StatSoft. 2003. STATISTICA, version 6. Available: www. statsoft.com. (January 2005).

Stuart, I. G., and M. Mallen-Cooper. 1999. An assessment of the effectiveness of a vertical slot fishway for nonsalmonid fish at a tidal barrier on a large tropical/ subtropical river. Regulated Rivers: Research and Management 15:575-590.

Svedäng, H., and H. Wickström. 1997. Low fat contents in female silver eels: indications of insufficient energetic stores for migration and gonadal development. Journal of Fish Biology 50:475-486.
Swaney, D. P., K. E. Limburg, and K. M. Stainbrook. 2006. Some historical changes in the patterns of population and land use in the Hudson River watershed. Pages 75-112 in J. R. Waldman, K. E. Limburg, and D. L. Strayer, editors. Hudson River fisheries and their environment. American Fisheries Society, Symposium 51, Bethesda, Maryland.

Tesch, F. 2003. The eel, 5th edition. Blackwell Scientific Publications, Oxford, UK.

Verdon, R., and D. Desrochers. 2003. Upstream migratory movements of American eel Anguilla rostrata between the Beauharnois and Moses-Saunders power dams on the St. Lawrence River. Pages 139-151 in D. A. Dixon, editor. Biology, management, and protection of catadromous eels. American Fisheries Society, Symposium 33. Bethesda, Maryland.

Vörösmarty, C. J., K. P. Sharma, B. M. Fekete, A. H. Copeland, J. Holden, J. Marble, and J. A. Lough. 1997. The storage and aging of continental runoff in large reservoir systems of the world. Ambio 26:210-219.

Walter, J. F., III, and H. M. Austin. 2003. Diet composition of large striped bass (Morone saxatilis) in Chesapeake Bay. U.S. National Marine Fisheries Service Fishery Bulletin 101:414-423.

Wang, L., J. Lyons, P. Kanehl, and R. Gatti. 1997. Influences of watershed land use on habitat quality and biotic integrity in Wisconsin streams. Fisheries 22(6):6-12.

Wolter, C., J. Minow, A. Vilcinskas, and U. A. Grosch. 2000. Long-term effects of human influence on fish community structure and fisheries in Berlin waters: an urban water system. Fisheries Management and Ecology 7:97-104. 